\title{
Plantation Agriculture and Social Control in Northern Peru, 1875-1933
}

Latin American Monographs, No. 62 Institute of Latin American Studies The University of Texas at Austin 
THIS PAGE INTENTIONALLY LEFT BLANK 


\section{Plantation Agriculture and Social Control}

in Northern Peru, 1875-1933

By Michael J. Gonzales

$\sqrt{ }$ University of Texas Press, Austin 
Copyright $(1985$ by the University of Texas Press All rights reserved

First Edition, 1985

Requests for permission to reproduce material from this work should be sent to:

Permissions

University of Texas Press

P.O. Box 7819

Austin, Texas 78713

Library of Congress Cataloging in Publication Data

Gonzales, Michael J., 1946-

Plantation agriculture and social control in northern Peru, 1875-1933.

(Latin American monographs; no. 62)

Includes index.

1. Sugar trade-Peru-History. 2. Sugar workers-Peru-History. 3. Plantations-Peru-History. 4. Social control. I. Title. II. Series: Latin American monographs (University of Texas at Austin. Institute of Latin American Studies); no. 62.

HD9114.P52G66 $1984 \quad 338.1^{\prime} 7361^{\prime} 09851 \quad 84-2359$

ISBN 0-292-76491-X 
To Gail, for helping me with every facet of this study and giving me valuable intellectual and moral support. 
THIS PAGE INTENTIONALLY LEFT BLANK 